\title{
Completing the GATS Framework: Addressing Uruguay Round Leftovers
}

\author{
Pierre Sauvé* \\ OECD Trade Directorate
}

This paper explores three ongoing areas of rule-making activity under the General Agreement on Trade in Services - emergency safeguards (ESM), subsidies and government procurement. It suggests that as policy makers turn their attention to a range of new issues in the context of a second set of GATS negotiations, it is essential that new impetus be given to completing what the Uruguay Round left unfinished.

The paper first examines the desirability, feasibility and prospects for developing multilateral rules on an emergency safeguard mechanism and trade distorting subsidies, in the context of the ongoing GATS negotiations. Using the existing framework of trade in goods as a model, the paper examines whether and how relevant GATT principles might be applicable in these two areas in the context of services trade. The paper suggests that the very feasibility of an ESM remains an open question, given the state of our knowledge of services trade. The paper cautions, however, that the clear political expectation on the part of many developing countries that concrete disciplines must arise from the current discussions suggests that it is likely that the GATS will feature some form of ESM in the future, much as its ultimate substantive provisions and operational modalities remain to be determined.

On subsidies, the paper suggests that the desirability of disciplines in this area will require a more thorough identification phase to determine the extent to which subsidies exist in services industries and result in adverse trade or investment effects. As with safeguards, the feasibility of subsidy disciplines will need to factor in the specificities of services trade and investment. While some guidance could come for the SCM Agreement, it is not a panacea.

The paper's third section turns its attention to whether and how disciplines governing public purchases of services should best be addressed under WTO law. The paper suggests that procurement regimes for services, even if explicitly discriminating against foreign suppliers, are unlikely to have major repercussions on domestic or foreign welfare so long as markets are contestable. The priority issue from a developing country perspective may therefore lie more in removing barriers to access (i.e. trade) and presence (investment) in goods and services markets and enforcing domestic competition laws than in developing a GATS-anchored set of procurement disciplines.

Keywords:

JEL-Codes:

GATS, trade in services, emergency safeguard measures, subsidies, government procurement, Doha Development Round F13, F15, K33

* The views expressed in this paper are those of the author and should not be ascribed to the Organisation for Economic Co-operation and Development or its member countries. The author is particularly grateful to SACHA WUNSCH-VINCENT for the excellence of his assistance in revising this paper. Thanks are also due to Rolf Adlung, Gilles Gauthier, Heinz Hauser, Aaditya Mattoo and Arvind SuBRAmanian for helpful comments and/or discussions. 


\section{Introduction}

In July 2002, a number of WTO Members submitted bilateral requests for specific GATS commitments to their fellow trading partners. The tabling of initial requests is one of the first actions required by the Doha Ministerial Declaration that set the objectives of a new WTO trade round ${ }^{1}$.

Services negotiations have been ongoing since February 2000. As mandated by GATS Art. XIX on progressive liberalisation, the GATS 2000 negotiations started independently of a comprehensive trade round. During the last two years, negotiators were busy agreeing on GATS negotiation guidelines and in making various sectoral and horizontal negotiating proposals ${ }^{2}$. The results and the objectives of these new service negotiations are now integrated into the more comprehensive Doha Development Agenda. The Doha mandate sets ambitious deadlines for the GATS negotiations: one deadline (June 30,2002) concerned the submission of initial liberalisation requests. Another deadline asks service negotiators to come up with an initial set of liberalisation offers nine months later (March 31, 2003). Initial requests are currently being discussed in special sessions of the Council for Trade in Services. Much negotiating attention is thus being absorbed by this work-intensive process of trying to secure a higher level of bound commitments on market access and national treatment under the GATS.

But the services negotiators embark on a second set of GATS discussions with much unfinished business left over from the Uruguay Round (1986-1993). Some sixteen years after the Uruguay Round's inception, the framework of GATS rules and disciplines is still very much under construction, with work outstanding on a number of key fronts. As can be seen from Table 1, the GATS built-in agenda in force since 1995 does not only mandate progressive services trade liberalisation via additional specific commitments. Negotiators were also instructed to develop certain GATS rules that could not be agreed upon during the Uruguay Round. These include: (1) emergency safeguards; (2) subsidies; (3) government procurement; and (4) domestic regulation.

1 The Doha mandate can be found in WT/MIN/(01)/DEC/W/1 (November 14, 2001), Ministerial Declaration of the Ministerial Conference (Fourth Session), Doha, page 3, para. 15.

2 Initial requests that concern more than 25 service sectors can be found at http://www.wto.org/english/ tratop e/serv e/s propnewnegs e.htm. Also, a relevant number of horizontal and multi-sectoral proposals have been submitted. The GATS negotiating guidelines and procedures can be found in S/L/93 (March 29, 2001).

Reproduced with permission of the copyright owner. Further reproduction prohibited without permission. 


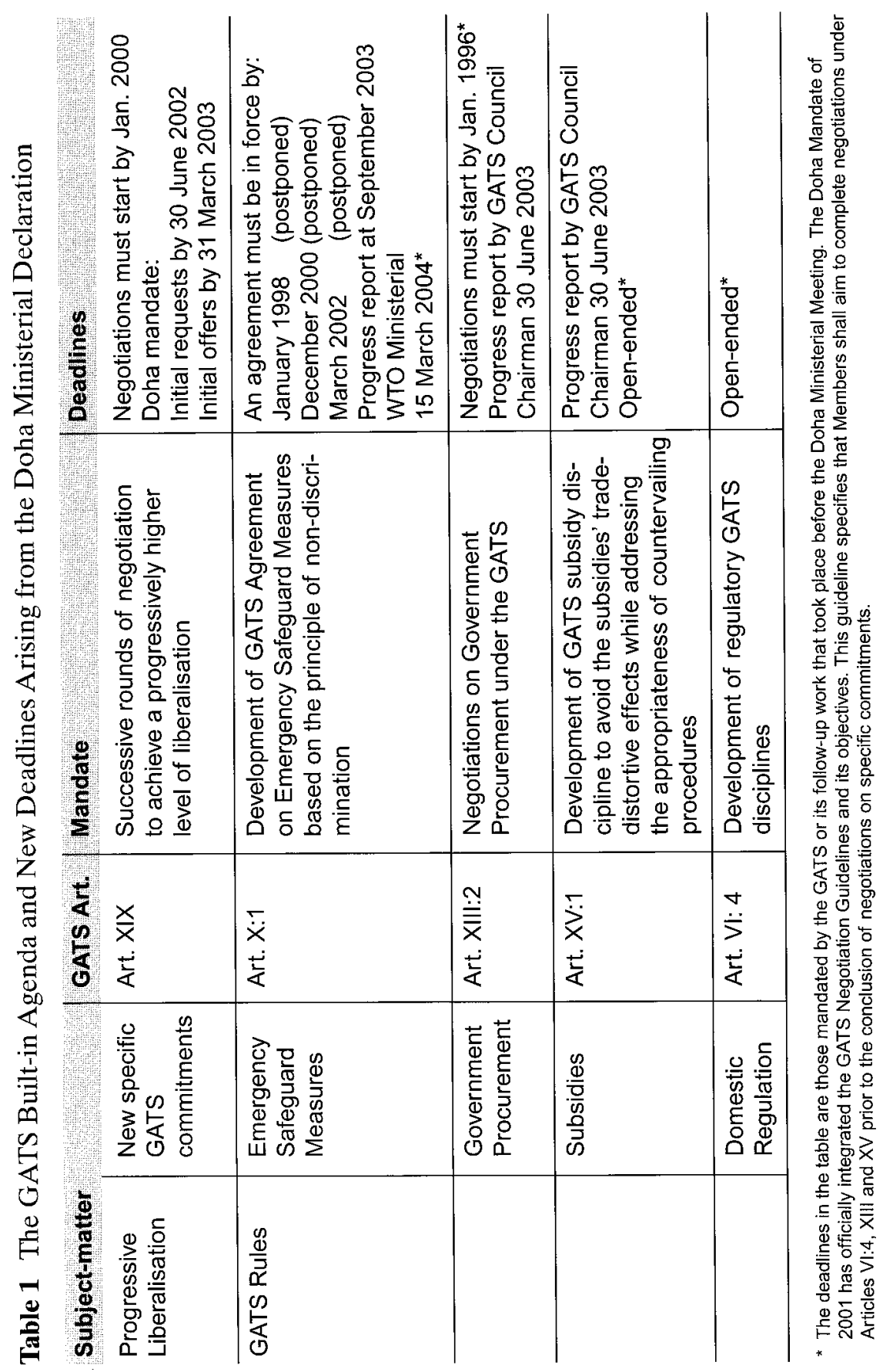

Reproduced with permission of the copyright owner. Further reproduction prohibited without permission. 
That the GATS should be seen as work in progress is hardly surprising when viewed in light of the remarkable diversity of activities it encompasses and the rapid pace at which developments in technology and regulatory approaches affect policy- and rule-making in the sector. GATS negotiators already confront important policy choices on a wide range of new fronts, ranging from calls to embed more comprehensive rules on investment, to the integration of generic competition policy disciplines targeting private anti-competitive conduct, or the development of rules aimed at facilitating services trade through electronic means.

Yet as they turn their attention to new rule-making and market opening challenges, it is essential that GATS members try to progress and/or bring closure to what the Uruguay Round left unfinished. This essay focuses on the first three components of the GATS' unfinished or "leftover" agenda: emergency safeguards, subsidies, and government procurement.

The period since the signing of the GATS treaty in 1994 has seen generally unsatisfactory progress made on this menu of leftover issues. As Table 1 shows, some leftover issues (e.g. emergency safeguards) had been earmarked for completion three years after the entry into force of the WTO Agreement (January 1998). Due to an inability to agree on the very need for - and substantive provisions of - a possible emergency safeguard mechanism, the Working Party on GATS Rules (WPGR) - a subsidiary body to the Council for Trade in Services - recently postponed the deadline for completing negotiations on such an instrument for the third time to March 2004 (6 years later!). In addition, close to seven years of negotiations on the other two components of the unfinished agenda (subsidies and government procurement) have not brought about significant results.

In part, such lack of progress reflects the fact that much attention was devoted during the 1994-97 period to completing outstanding sectoral negotiations, particularly in the high-stake areas of telecommunications and financial services. But it is also reflective of a number of other forces. In the case of emergency safeguards and subsidies, problems have arisen from the sheer technical complexity inherent in developing disciplines in hitherto uncharted waters. Safeguards and subsidy disciplines have a long history in trade in goods ${ }^{3}$. Although lessons can be drawn from these existing GATT instruments, the development of the same tools for trade in

3 Present since the inception of the GATT, in 1947, they have now developed into full-blown mechanisms governed by distinct sets of rights and obligations set out in Annex 1A of the GATT 1994. 
services is much more difficult, owing to the more complex nature of services transactions. Throughout the discussion of the three components of the leftover business it will be seen how the GATS distinction between four modes of supplying services across borders (cross-border trade, consumption abroad, commercial presence and presence of natural persons ${ }^{4}$ ), the measurement problem with respect to international services transactions, the conceptual difficulty of defining "like services", and other conceptual difficulties, have all conspired to slow down the negotiating process.

In the case of government procurement, progress has doubtlessly been hampered by the somewhat schizophrenic manner in which WTO members have approached the subject, with calls for the development of multilateral disciplines for services procurement sitting alongside existing plurilateral disciplines already applying to services (and goods) under the Government Procurement Agreement (GPA) as well as calls for a set of multilateral rules on transparency and due process in public purchasing. Complicating the matter further, calls for a set of multilateral rules on transparency in government procurement have now been echoed in the Doha Declaration.

Progress on unfinished business has also been affected by the fact that each of its components touches upon sensitive policy areas and involves some degree of tension along North-South lines. The difficult negotiating environment that has emerged since the failed Seattle Ministerial Meeting in December 1999 has further compounded such difficulties. Since Seattle, WTO Members' every move has become subject to the close scrutiny and the critical assessment of civil society groups. The latter have of late become especially vocal in the services field ${ }^{5}$. The increased public fear that services trade liberalisation is largely synonymous with far-reaching deregulation has generally prompted governments to adopt a more cautious attitude on these issues. These considerations add a new layer of political and tactical/bargaining considerations which tend to cloud and confuse the underlying economics of the policy debates at hand.

\footnotetext{
4 These are the four GATS modes as specified under GATS Art. I:2.

5 Some of these comments that are sometimes based on misunderstandings about the GATS have led the Trade in Services Division of the WTO to explain the GATS-related facts and to address a number of misunderstandings or indeed fictions arising in the public policy debate surrounding the GATS. See WTO (2001) and OECD (2002).
} 
Finally, it may be that these technically and politically complex negotiations are not easily addressed outside of the context of a larger WTO trade round. First, absent a more comprehensive round, WTO Members cannot trade off concessions through cross-cutting deals where a multitude of rule-making issues on different subjects is involved. Second, the work undertaken in GATS Working Groups may not have gotten the political visibility and attention necessary to reach agreement on difficult issues. As well, in a more comprehensive negotiation that entails a more explicit link between rule-making and additional GATS commitments, it may be easier to mobilise support from pro-GATS interest groups (users and service suppliers).

Despite the above challenges, it is imperative that the unfinished business of GATS be tended to in the context of a new trade round. This need for action has in fact been formalized in the GATS Negotiating Guidelines that have been taken over by the Doha Mandate. The latter makes explicit that negotiations under Articles X, XIII and XV must be concluded prior to the conclusion of negotiations on specific commitments (at the latest by January 2005$)^{6}$.

In this respect, it remains an open question how such negotiations might be affected by their integration into a more comprehensive new trade round. Although there is a risk in the Doha Round that the attention of the negotiators will be drawn to other issues, it is almost certain that work on the unfinished agenda of the GATS will receive new impetus. In particular, the circular interplay between already existing commitments, negotiations on new specific commitments and the development of GATS rules will be of great interest. One may expect an inherent reluctance of WTO members to introduce GATS rules belatedly to the agreement that then apply fully to past specific commitments. Yet some WTO members may feel uncomfortable in entering new GATS commitments without knowing more about the rules on ESM, subsidies and government procurement that will be applicable in the future. As will be seen, for some WTO members, particularly developing countries, the introduction of an ESM instrument may even be a pre-condition for further liberalisation.

The rest of this paper is divided into four parts. The next two sections examine the desirability, feasibility and prospects for developing multilate-

\footnotetext{
6 See the GATS Negotiation Guidelines and Procedures in WTO document S/L/93 (March 29, 2001), part II. The Doha Mandate does not make explicit reference to the development of these GATS Rules. However, it recognizes the guidelines as a basis for pursuing the services negotiations.
} 
ral rules on an emergency safeguard mechanism and trade distorting subsidies, in the context of the ongoing GATS negotiations. Using the existing framework of trade in goods as a model, the paper examines whether and how relevant GATT principles might be applicable in these two areas in the context of services trade. The paper's fourth section turns its attention to whether and how disciplines governing public purchases of services should best be addressed under WTO law. The final section offers a few concluding remarks.

\section{Emergency Safeguards}

\subsection{Defining safeguard measures}

The term "safeguard" can be used to describe various "escape clauses" that can be invoked for different circumstances ${ }^{7}$. For the purposes of this paper, the term "emergency safeguards" is used to describe a mechanism that can be invoked by governments, under specified conditions, to impose or increase protection in order to relieve, on a temporary basis, difficulties or pressures that have arisen as a result of liberalisation commitments and obligations undertaken in trade agreements. The main features of a temporary safeguard are that it targets a specific product or industry, is applied on an MFN basis, is of limited duration, is sometimes progressively liberalised over the period of its application and, in some cases, is subject to demands for compensation from other Members affected by the measure. Another key element of this type of measure is that increased imports resulting from the liberalisation are causing or threaten to cause "injury" to domestic producers of the like or directly competitive product. Examples of this type of safeguard can be found in GATT Article XIX, the Agreement on Safeguards, Article 5 of the Agreement on Agriculture and Article 6 of the Agreement of Textiles and Clothing as well as in numerous regional trade agreements, including the NAFTA and most Association Agreements concluded between European Union members and various countries.

\footnotetext{
7 In its broadest sense, it can refer to provisions which permit measures to be "safeguarded" from the application of the obligations of the agreement. General exceptions, such as those found in GATT Art. XX, GATS Ar. XIV and the national security provisions, are examples. The term "safeguard" can also refer to the ability to change or modify a commitment. Art. XXI of the GATS and Art. XXVIII of the GATT contain such a mechanism providing a safety valve for a government that decides, for one reason or another, to withdraw a concession, subject to the requirement that it make compensatory adjustments in return. The GATS and the GATT also provide for the temporary imposition of restrictions on trade to "safeguard" against a serious deterioration of the country's balance of payments situation.
} 
In the context of GATS negotiations on emergency safeguard measures (ESM), it would appear appropriate to use a definition that resembles most closely this latter category - i.e., an emergency mechanism directed at offering temporary protection to a domestic industry which is seriously injured by liberalisation. The other types of measures that can be associated with the notion of a safeguard - general exceptions, renegotiations of commitments, measures necessary to protect the balance of payments, to which measures taken on prudential grounds could be added - while relevant from an overall policy standpoint, are arguably not suited to dealing with the same sort of circumstances ${ }^{8}$. While they are clearly not substitutable for an ESM, their role and function still provide useful guideposts to circumscribe the scope of an eventual ESM. In other words, in considering the question of an ESM, policy makers must be mindful that these others instruments do exist and that any such ESM should not apply to circumstances already contemplated by existing provisions.

\subsection{The Economic Case for Safeguards}

Historically, the existence of an emergency safeguard measure in a trade agreement arose from the perceived need for some form of safety valve in the event of unforeseen problems created by the liberalisation of trade. Protection of domestic suppliers has been an explicit objective. By addressing concerns over potential "unforeseen problems", it attempts to respond to a dual motive. On the one hand, it has been argued that the existence of an ESM might help persuade domestic constituencies to accept greater liberalisation. On the other hand, it may also serve to allow breathing space for a domestic industry to adjust to new competitive realities.

However, in looking at the historical record of emergency safeguards measures applied to goods trade, their usefulness in terms of securing greater liberalisation and facilitating adjustment is difficult to verify empirically ${ }^{9}$. Very few examples of successful liberalisation directly associated with the presence of a safeguard provision can be found. Not surprisingly, negotiators tend to attach far greater importance to the perceived degree of sensitivity of the industry or sector than to the availability of a safeguard clause in agreeing to any given level of bound liberalisation.

\footnotetext{
8 MESSERLin (1997)

9 MESSERLIN (1997)
} 
Moreover, it is worth recalling that safeguards are directed at "unforeseen" consequences, whereas negotiators operate on the basis of risk assessment of how particular sectors would cope with increased foreign competition.

In addition, the argument regarding adjustment is also not very compelling. The economic literature suggests that there are economic costs associated with protection devices such as safeguards. Safeguard actions tend to increase prices and impose additional costs on consumers that outweigh the benefits to the recipient industry, resulting in a net welfare $10 \mathrm{ss}^{10}$. At the microeconomic level, there is little empirical evidence suggesting that domestic industry actually does take the appropriate steps to "adjust" to conditions of competition when given the opportunity during the application of a safeguard measure. In short, a safeguard may perform a useful function in temporarily appeasing domestic concerns, but it is no panacea for substantial adjustment.

But while the availability of a safeguard measure might not in itself be the determinative factor for securing greater overall liberalisation, it might nonetheless be useful from a political economy standpoint to help temper opposition to liberalisation. As in any negotiated package, the key test is to be able to publicly defend the result as being balanced, reflecting both export and import interests at play. Officials may be able to point to the availability of a safeguard provision to suggest that "defensive" interests have been taken into account. This holds especially for sectors where no ex ante assessment of the possible effects of liberalisation has been conducted. It is not coincidental that safeguard measures are common features of virtually all trade agreements. This reflects the political value they bring to the liberalisation process as a whole, even though the presence of safeguards may not have a decisive impact on the magnitude of the commitment on a sector by sector basis. As will be seen later, the political value of safeguards is very present in the current negotiations.

But there is a further rational argument in favour of an ESM instrument. Some WTO members have argued that the GATS Art. XXI on the modifications of schedules offers enough flexibility to react to emergencies ${ }^{11}$.

10 BALDWIN (1992)

11 GATS Art. XXI:1 states that "A Member (referred to in this Article as the 'modifying Member') may modify or withdraw any commitment in its Schedule, at any time after three years have elapsed from the date on which that commitment entered into force, in accordance with the provisions of this Article". Compensatory adjustments must be negotiated with the concerned trading partners if this clause is invoked. 
But it may well be argued that an additional agreement on safeguards that allows for coordinated and temporary restrictions on commitments is a more desirable policy approach. After all, the withdrawal of commitments may set an undesirable precedent. Under these circumstances, a temporary crisis may trigger the permanent withdrawal of commitments and the economic benefits deriving from them. Moreover, the difficulties arising in reaching agreement on compensatory adjustments as postulated by Art. XXI:2(b) raise very similar problems of measurement and other conceptual problems involved in the implementation of a safeguard measure.

Turning more specifically to services, the debate among WTO Members has yet to identify precise examples of potential circumstances where an ESM might be required. Indeed, the discussions have largely been in the abstract. This may be symptomatic of the overall context in which the discussions on these GATS rules are taking place. The GATS is still in its early days of existence. With few exceptions (e.g. basic telecommunications), actual liberalisation has been modest, with the vast majority of bindings reflecting the regulatory status quo (and sometimes considerably less), thereby minimizing the scope for the "unforeseen" scenario. Moreover, in view of the positive listing of scheduled commitments, the option of not making a commitment is always a negotiating possibility. Such regulatory freedom largely obviates adjustment pressures in sectors where countries may not deem domestic competitors capable to withstand extra doses of competition.

The application of an ESM in services trade would not be without its own economic consequences. As for trade in goods, the use of an emergency safeguard would limit access to services from foreign suppliers, and generally maintain higher prices than would arise under conditions of more open competition. Since many services play an important role as key infrastructural inputs in all economies, restricting their supply might have adverse economy-wide effects. In fact, the effects could be significant considering that a proportion of the productivity gains of recent years can be attributed to declining costs of transport and telecommunications, greater sophistication of financial intermediation, as well as marked improvements in distribution systems and logistics, among others. Although the economic case for safeguards is generally weak, the next sections will shed light on the feasibility and possible form of a GATS ESM instrument. 


\subsection{Applying the GATT Safeguards Paradigm to Trade in Services: Conceptual and Practical Challenges}

If WTO members are to look at GATT Article XIX as a possible template for services, it is essential to understand its structure and main operational modalities. While GATT Article XIX uses the concept of "unforeseen" developments, it bears noting that this is not replicated in the Uruguay Round Agreement on Safeguards ${ }^{12}$. Rather, the negotiators of the latter agreement developed more precise tests governing the application of safeguard actions. The Agreement on Safeguards essentially imposes a two-stage test: (i) imports must have increased in absolute quantities or relative to domestic production - implicit here is the notion of a surge in imports or import shares; and (ii) imports must cause serious injury to a domestic industry producing like or directly competitive goods.

The first concept involved is that of "imports". In the services context, its application is not straightforward. The picture is complicated by the fact that there are four modes of service delivery ${ }^{13}$. Thus, one of the first concerns negotiators encounter in attempting to apply an Article XIX-type mechanism to services is of deciding whether such a mechanism could be designed to apply to what one would typically think of as "import" situations (i.e., cross-border trade) and whether it could (or should) be designed to apply to situations involving services supplied through any one of the three other modes of delivery.

Mode 1, cross-border trade, does not pose particular conceptual difficulties because there is an "import" in the traditional sense and the limitation on trade can take the form of constraining sales of foreign service suppliers in the importing country. For mode 2, the "import" transaction takes place in the exporter's market. Under this mode, it is the customer that crosses the border to consume the service abroad. Any limitation on services trade would mean limiting the ability of the customer - as opposed to the supplier - to consume services abroad. In mode 3 , the situation is even more complex since the transaction involves the establishment of the service supplier in the importing country. There is a dual dimension to the "importation" issue: the establishment of a commercial presence in a

12 See also WTO document S/WPGR/W/8 (March 6, 1996), Emergency Safeguard Measures in GATS: The Applicability of Concepts applied in the WTO Agreement on Safeguards - Note by the Secretariat and WTO document S/WPGR/W/1 (July 6, 1995), Emergency Safeguard Measures under Art. X of GATS - Note by the Secretariat.

13 Art. I of GATS defines trade in services as consisting of the following four modes of supply: (i) cross-border supply; (ii) consumption abroad; (iii) commercial presence; and (iv) movement of natural persons. 
host country, and the sales or domestic operations of the established foreign supplier. The former may be dealt with via a limitation on foreign investment. But the latter cannot conceptually be considered as an "import". As regards mode 4, the application of the concept of "import" to movement of persons appears rather incongruous ${ }^{14}$.

Since the traditional purpose of an ESM is to provide short-term import relief to the domestic industry, the right to bring a complaint should be that of the "domestic industry". In the services context, the domestic industry could be composed of domestic service suppliers and/or foreign service suppliers that have established a commercial presence. In this case, the question arises as to whether the term "domestic industry" should include all service suppliers located within the territorial limits of a country or whether the locally established service suppliers of foreign companies should be excluded. If locally established foreign service suppliers are excluded, negotiators must then consider the ramifications of classifying their services as "imports" and thereby possibly making them subject to whatever safeguard measure is imposed. In addition, the exclusion of foreign suppliers established in the domestic market raises the obvious problem of national treatment.

The next problem confronting WTO members is to sort out what constitutes "like or directly competitive services". The very nature of services trade makes this determination somewhat more tenuous since so much of what is delivered as a service is tailored to meet customer needs. In addition, the intangible nature of service provision creates difficulties in trying to compare a foreign service to a domestic service. Moreover, the concept of "like or directly competitive" assumes still greater complexity in determining whether a service supplied on a cross border basis is similar to one supplied through one of the other modes of supply.

Establishing what constitutes the "domestic industry" and "like services" is critical to credibly determining whether imports may be causally linked to whatever injury is suffered by a country's domestic industry. The determination of injury also raises a challenge of its own, in particular the necessity to establish causality. Equally daunting challenges arise in attempting to demonstrate whether there has been a "surge" in imports of the like or directly competitive product. Due to the well-known weaknesses of

14 One could however argue that the use of an economic need test represents a form a safeguard measure since it directly relates to the capacity of the host country to absorb the additional entry of foreign personnel.

Reproduced with permission of the copyright owner. Further reproduction prohibited without permission. 
statistical reporting in services trade, there could be serious constraints to the gathering of sufficient information in a timely manner to provide the basis for a conclusion on the question of surges of imports, and of the injury that has been potentially suffered.

Any measure is only useful to the extent that it is administratively sound and enforceable. There may yet be other serious challenges here. For instance, how would a safeguard measure apply to the growing share of trade in services taking place over electronic networks under modes 1 and 2 ? Stated differently, how should GATS members deal with the growing importance of electronic commerce in developing safeguard provisions? As well, how would a measure deal with established firms under mode 3 where there is not even a "border" related transaction? Would a safeguard action include forced divestiture or grandfather the operations of established operators and apply solely to prospective investors? Could such a distinction provide credible relief to injured domestic suppliers?

The foregoing highlights the significant conceptual and practical problems associated with a generic ESM modeled on trade in goods for services trade. In view of this, if an ESM is to be negotiated, a new approach would be needed to better reflect the intricacies of the GATS, in particular those arising from the multiplicity of modes of supply; to relate more appropriately to the conditions of competition in services trade; and to better balance the various interests at play.

\subsection{The Link Between New Specific GATS Commitments and Emergency Safeguards}

The discussion so far has shown that the economic case for safeguards is somewhat uncertain and that there exist significant conceptual and practical problems in devising a services-specific ESM measure. This could lead to the impression that the lack of rational arguments in favour of such an instrument should prompt negotiators to throw in the proverbial towel and abandon attempts at developing a GATS ESM. In fact, this is the desired scenario of a number of countries - mostly from the OECD area - a vast majority of which believe that the GATS offers enough flexibility to deal with all sorts of unforeseen adverse circumstances.

However, this impression would negate the political reality of the ongoing discussions on emergency safeguards for services and the different negotia- 
tion positions of industrialized and developing countries in this regard. Although members like the EU and the US may not believe in the economic case for safeguards, they cannot summarily dismiss two points: the political economy imperative for developing safeguard disciplines ${ }^{15}$ and the contractually guaranteed promise of a GATS agreement on emergency safeguards. Both points create a vital link between the development of an ESM agreement and the successful negotiation of new specific GATS commitments.

Concerning the former point, safeguards may perform an "insurance policy" function by encouraging GATS members to undertake more liberal commitments than they would otherwise be prone to consider in their absence. Moreover, more Member States may be inclined to bind the regulatory status quo rather than schedule commitments that do not lock in what is already afforded under domestic law. Such a safety valve could well assist the negotiations by allaying the concerns some developing countries harbour with regard to opening their fledgling services markets to outside competition. Clearly, these new areas of liberalisation have a higher degree of uncertainty that tends to bring great regulatory precaution during multilateral negotiations. As regards the latter point, since the Uruguay Round WTO members are under the contractual obligation to conclude an emergency safeguard agreement by $1998^{16}$. It would be fair to assume that a number of developing countries may well have agreed to make Uruguay Round commitments under the GATS on the understanding that an ESM instrument would eventually be agreed upon. In the current negotiation context, especially the Association of Southeast Asian Nations (ASEAN) group but also countries like Brazil and India have continued the adoption of an emergency safeguard instrument. Any derogation from this treaty-specific obligation will certainly not stimulate the developing countries' trust to make new specific commitments and to believe in the industrialized countries' goodwill with respect to the affirmed "developmentfocused Doha agenda"17.

15 GAUthier ET AL. (2000) and Bosworth (2000)

16 GATS Art. X:1

17 In fact the GATS negotiation guidelines and the Doha Ministerial Declaration provide for the special treatment of the developing countries with respect to several elements. Developing countries will pay particular attention to these mandated objectives. Unfortunately, there are already first signs that the industrialised countries may not live up to these expectations. For instance, assessments of trade in services before any negotiations on commitments - mandated by GATS XIX:3 and GATS negotiation guidelines, part III - which should have helped the developing countries to develop their negotiation position, have not been undertaken so far. In addition, the developing countries have not received much technical support for the drafting of initial requests. 
Clearly, the industrialized countries do appear to show greater understanding for the political economy argument in favour of an ESM. In the ongoing Doha Round, the EU and the US have both shown their clear interest in deepened market access and national treatment commitments on the part of developing countries. Thus, although OECD countries do not generally regard a GATS ESM instrument as desirable and feasible, they can be expected to aim for a trust-creating environment that does not neglect the strong will of a large group of developing countries to reach agreement on the ESM issue.

In short, discussions over the question of a GATS ESM will increasingly be linked to the discussion of new liberalisation commitments on the part of developing country WTO members. This causality will be fostered by the fact that through the Doha negotiations, the negotiations on rules and commitments (request-offer process) are now less compartmentalized. A submission by the US government in October 2001 featured a de facto ultimatum that provoked strong reactions on the part of developing countries $^{18}$. In its position paper, the US stated very clearly that it was not willing to discuss the details of an ESM if, in return, developing country WTO Members were not ready to make improved commitments in the market access negotiations ${ }^{19}$. In addition, the US paper argued that safeguard measures should apply solely to new commitments and not to commitments made during (and immediately after) the Uruguay Round. Such a formalized quid pro quo was not greeted with much enthusiasm on the part of developing countries.

All in all, the issue should be viewed in the aggregate and as a negotiated outcome, whereby the introduction of an ESM is looked at in conjunction with further liberalisation. Clearly, agreeing on an ESM will to an important degree depend on the OECD countries' assessment of whether developing countries are likely to agree to make commercially meaningful GATS commitments in the absence of such a safety valve. It may nonetheless be said that an agreement has grown more likely through the link with the negotiations on specific commitments and the fact that such talks are now embedded into a more comprehensive trade round. New impetus can also be seen from the fact that the fourth postponement of the deadline was only accepted by the ESM demandeurs because the negotiating

18 WTO document S/WPGR/W/37 (October 02, 2001), Communication from the United States.

19 BRIDGeS WeEkLy TRade News Digest, Vol. 5, Number 40, November 28, 2001 and BRIDGES Weekly Trade News Digest, Vol. 5, Number 41, December 04, 2001. 
parties agreed to hold a stocktaking exercise during the Fifth Ministerial Meeting in 2003 and because it was agreed to establish a work program in the Working Party on GATS Rules (WPGR) to structure the future work on safeguards and aim for a draft model quite soon.

\subsection{Designing an ESM for Services Trade: Some Rules of Thumb}

For reasons described above, there are grounds to believe that WTO members will heed the political expectations of a large number of developing countries and devise an operational ESM in time for the new 2004 deadline. A series of criteria or rules of thumb may be of help for this to occur.

First, discussions will need to more clearly articulate the types of circumstances for which a GATS safety valve is not already provided. To date, the only such circumstances that appear relevant are those characterized as "unforeseen problems caused by liberalisation commitments". It remains incumbent on countries favouring the adoption of a GATS ESM to better argue their case, and in particular to propose objective tests that would more readily allow the identification of such circumstances, especially in light of the difficulties that are associated with concepts such as "imports", "like services" and "like service providers", as well as the overall paucity of relevant data with which to make credible assessments of import surges and injury determinations.

On a second level, it will also be important to find an appropriate balance between an ESM that purports to meet the genuine concerns of those countries that have yet to schedule a significant amount of liberalisation commitments across their services sectors, and an ESM which could be open to abuses and become a favoured instrument of protection.

Thirdly, the potential negative economic effects of the application of an ESM as it affects both domestic and foreign service suppliers will need to be taken into account. It should be recognised that provision for - and subsequent use of - an ESM should be on the condition that it is triggered only for the purpose of granting domestic service suppliers an appropriate amount of time to adjust to the potentially disruptive effects of newly competitive conditions. Accordingly, the application of an ESM should be time bound and allow some scope for progressive liberalisation. In addition, because it is unclear how commitments made at a level 
below the existing regulatory or statutory status quo - a feature common to many developing country schedules under the GATS - could be deemed responsible for serious injury to domestic or established suppliers, a requirement for any GATS ESM is that it should be invoked solely in instances where the petitioning country has either scheduled de novo liberalisation or at a minimum locked in the regulatory status quo. The overall indirect effect of such a rule would be enhance the quality of bound liberalisation undertakings under the GATS.

In addition to the above considerations, the main issue of implementation is whether a GATS ESM should apply indiscriminately to the four modes of delivery ${ }^{20}$. Should GATS members decide not to apply an ESM to all four modes of supply, a question could arise as to the effectiveness and equity of application of the measure. An initial observation would suggest that due to the lack of uniformity in members' scheduled commitments and the potential for an uneven impact on differing modes of supply, it is not clear how equitable the application of such a measure could be. Moreover, the argument can be made that applying the ESM to one mode only is inequitable because it would unreasonably penalise service providers that conduct their business within one mode versus those who are diversified and conduct (or have the capacity to conduct) their business through various modes. This may well in effect penalise certain sectors and trading partners more than others and raise de facto discriminatory concerns. In addition, the effectiveness of application of an ESM to one mode could be reduced as it might lead to a diversion of supply through another mode to avoid ESM restrictions.

But credible arguments against an ESM applicable to all four modes can also be found. Although limitations to mode 1 transactions may not pose conceptual difficulties, they may be hard to enforce in practice ${ }^{21}$. Indeed, potential limitations to cross-border service trade would likely entail somewhat unrealistic or unfeasible border checks on various types of crossborder transactions, particularly in the case of telecommunications or ecommerce transactions. Similar enforcement problems exist with respect to emergency safeguards relating to mode 2 transactions. There are gene-

20 See WTO document S/WPGR/W/38 (January 21, 2002), Communication from the EC and their Member States for some considerations on the modal application of an emergency safeguard measure.

21 See for some of these points WTO document S/WPGR/W/38 (January 21, 2002), Communication from the EC and their Member States for some considerations on the modal application of an emergency safeguard measure. The main point of the position paper is that the application of safeguard measures raises concerns in all four modes. 
rally few appropriate governmental means and motivations to control the consumption abroad of a country's own nationals. At the other end of the spectrum are limitations on mode 4 transactions, which can be relatively easily enforced by efficient border control of the entry of foreigners and through visa granting policies. Nevertheless, a problem may arise in view of the fact that mode 4 limitations can have a negative impact on the key personnel categories typically linked to mode 3 commitments. Moreover, mode 4 ESM limitations could adversely affect those developing countries that have strong comparative advantages in the provision of labourintensive services.

Still, by far the most problematic aspect of the application of a GATS ESM concerns mode 3 trade - commercial presence. Whereas the industrialized countries argue that foreign direct investment (mode 3) should be excluded from the scope of an eventual ESM, India and the ASEAN group of countries continue to push for mode 3 to be included ${ }^{22}$. Several considerations are warranted in this regard. First, any agreed rule would have to specify whether the safeguard would claw back on existing investment, i.e. provide for the divestiture of existing foreign operations. From an economic and policy standpoint, there would appear little justification for such a scenario. Not only does the foreign establishment generate genuine domestic economic activity, but it is hard to imagine that its divestiture will help domestic suppliers to eventually adjust to a new and more open competitive environment. Secondly, there could be serious adverse consequences for the attractiveness of a country's foreign investment regime. In a world characterised by fierce locational competition to attract foreign direct investment, it is not clear that a country would find this to be in its longer-term economic or developmental interests. Thirdly, a very large number of WTO Members are parties to bilateral investment protection agreements providing for rules against forced divestiture and exposing governments to compensation claims. Such considerations beg the question of whether it might not be simpler (and more efficient) to use government funds to assist the adjustment of "domestic" firms in the market instead of buying off foreign competitors.

Assuming, as seems likely (and desirable), that forced divestiture is ruled out, the issue then becomes whether mode 3 should be covered in any event, including when the primary concern is in respect of cross-border trade. The problem here becomes the interplay between modes 1 and 3 . It

BRIDGES WeEkLy TRADE News Digest, Vol. 5, Number 25, July 03, 2001. 
is not hard to imagine a situation where an ESM applied to cross-border trade would simply entice a foreign supplier to jump the barrier by establishing itself in the importing market. Does it make sense from a trade policy perspective that a protection device such as an ESM be used in fact as a TRIM-like instrument to spur foreign investment? Examples of such concerns have sometimes been raised in trade remedy cases in goods trade, notably in respect of anti-circumvention rules in the European Union. At first glance, there would thus appear to be a robust case for ensuring that a GATS ESM provides for coverage of mode 3, at least to avoid introducing an investment distortion. Perhaps a temporary "freeze" on new commercial presence by foreign suppliers (or on the further geographical or product range expansion of established foreign operators) in the relevant services industry would be an adequate mechanism in this context.

\subsection{Possible Approaches}

The discussion so far has begun to reveal the core elements that should govern the possible development and adoption of an ESM in the services context. First, it should not duplicate other measures that can be associated with existing "safeguard-like" features of the GATS, in particular the positive approach to scheduling commitments, Article XXI (modification of schedules of commitments), the provisions related to prudential measures, the balance of payments and general exceptions. Second, the analysis suggests that the GATT Article XIX-type of temporary safeguard would be difficult to transpose in a services context. Third, negotiators should be informed by lessons arising from the political economy of trade remedy protection, so as to ensure that new rule-making initiatives do not nullify or impair the purpose of liberalisation. Fourth, attention needs to be paid to certain basic criteria, or rules of thumb, in particular the link to adjustment and liberalisation, and the non-discrimination principles that would be relevant to the consideration of an eventual ESM. There is, finally, the need to account for the sectoral heterogeneity of services and the fact that trade is carried out through four different modes of delivery.

This paper has advanced several reasons why - despite the above-mentioned problems - it is still possible that a consensus favouring the adoption of a GATS emergency safeguard clause could emerge. Three scenarios could be envisaged with respect to the form of this new instrument. 
One such scenario, which commands a fair amount of support among developing country GATS members, would involve the development of a full-blown horizontal safeguards regime for services along the lines suggested by a set of submissions by ASEAN countries ${ }^{23}$. In what arguably represents the most detailed blueprint for a GATS safeguard clause submitted to date in the Working Party on GATS Rules (WPGR), countries from the Association of South-East Asian Nations (ASEAN), led by Thailand, have argued that services liberalisation can have unforeseen consequences on national economies. Citing the example of the effects of financial liberalisation in the recent Asian financial crisis, ASEAN countries have argued that countries should have recourse to an emergency safeguard to restrain foreign service providers. The ASEAN proposal, which was first presented to the WPGR in March 2000, uses the same standard as applied to goods trade for establishing proof of injury to domestic industry for all four modes of supply. It would require a showing that the injury, or threat thereof, is caused by increased supply of services by foreign service suppliers. The ASEAN proposal also outlines proposals to give developing countries more favourable treatment in the imposition of a safeguard. It would prohibit imposition of the safeguard against developing countries that have a small share of the market. It would also allow developing countries to impose safeguards for longer periods depending on the severity of the measure imposed.

The most problematic mode of supply on which to impose a safeguard is on foreign firms that have established a commercial presence in a foreign country to provide a service because of the difficulty in restricting firms already established. The ASEAN proposal describes three options for how a safeguard would be imposed for this mode of supply. Such options suggest that there is still no consensus among these nations for how restrictive the safeguard should be. The first, least restrictive, option would largely guarantee service suppliers who already have established commercial presence in foreign countries to maintain and expand their businesses, while restricting new entrants. The second option would prohibit expansion of business activities and additional capital investment of service providers by limiting the extension of rights. The third option would be even more restrictive, limiting businesses' acquired rights to those that have actually been exercised.

23 See Inside US TRAde (2000) and S/WPGR/W/30 (March 14, 2000), Communication from ASEAN. 
One of the debates likely to emerge on the issue is whether the proposed safeguard would violate the spirit of most-favoured nation commitments by imposing greater restrictions on new entrants than on those who have a head start in establishing a commercial presence in a host country. However, because new entrants from all countries would face similar restrictions under a safeguard, the argument has been made in the WPGR that it does not violate the letter of MFN commitments.

The ASEAN proposal does not enjoy full support among developing countries, some of which have voiced concerns over the fact that a GATS ESM could most easily lend itself to imposing restrictions on the movement of natural persons, one of the modes of services delivery that many such countries are keen to liberalise further in the current GATS round of talks. Of the four modes of service supply that the safeguard could potentially restrict, delivery via the movement of natural persons across borders is indeed the easiest to restrict, for example by imposing entry quo$\operatorname{tas}^{24}$. The ASEAN proposal responds to this concern by including a prohibition against imposing the safeguard against temporary entry of natural persons from developing countries if they account for less than a certain percentage of the labour market.

A number of "lighter" versions of the full-blown ASEAN proposal for a horizontal ESM instrument have been advanced. The most prominent other negotiation proposal, a joint Chilean, Costa Rican and Swiss Nonpaper, was supposed to stimulate the discussion in the WPDR ${ }^{25}$. In their paper, the three countries raised a series of pertinent questions on the possible scope, definition and the conditions of application for an ESM. In addition, the paper focuses on transparency, surveillance, and special and differential treatment for developing and least developed countries (LDCs). Although the communication makes clear that submitting country delegations do not favour the adoption of a GATS ESM, it advances a number of elements that should apply in the case of the creation of ESM. These include:

- a horizontal approach as opposed to a service sector-by-sector approach should be chosen;

- mode 3 should be excluded;

24 Especially, India fears that emergency safeguards will in fact not serve developing countries but may be used against them when it comes to the supply of services by natural persons. See BRIDGES Weekly Trade News Digest, Vol. 5, Number 40, November 28, 2001.

25 See the communication of Chile, Costa Rica, and Switzerland on "Possible Comprehensive Approach for an ESM", WTO non-paper and BRIDGES WEEKLY TRADE News DigeST, Vol. 5, Number 26, June 12, 2001. 
- a necessity test should apply and the duration of a measure should not exceed a maximum of 27 months;

- an institutional mechanism of surveillance should be created;

- Special and Differential Treatment (SDT) for developing countries and LDCs should be applied (like the extension of duration of an ESM).

One major difference between this joint paper and the ASEAN proposal lies in the exclusion of mode 3 from the ESM measures and in a tighter control concerning invocation of such safeguards (e.g. necessity test). A recent proposal by Australia that WTO Members applying an ESM should be required to notify the safeguard measure and to consult with the Member(s) affected by the ESM was welcomed by the negotiating parties $^{26}$.

A second option could be to dismiss the idea of a horizontal ESM instrument and to direct WTO Members to inscribe emergency safeguards in their schedules for individual sectors, with a set of general disciplines or criteria conditioning their use ${ }^{27}$. Some of the sector-specific measures to condition an ESM have also been taken up in above proposals for a horizontal instrument. They would:

- only temporarily delay liberalisation (i.e., no permanent back-tracking would be possible);

- be a one time measure only, of limited duration (i.e., a defined short period), and perhaps include progressive liberalisation;

- be triggered only by non-discretionary, objective events, based on statistical results (i.e., transparent domestic procedures);

- require specificity in terms of sectors and modes of supply; for mode 3, there should be no right to seek divestiture;

- require appropriate notification and reporting obligations (modeled on article 12 of the Agreement on Safeguards);

- be applied on an MFN basis.

The complex issue of compensation would also need to be addressed. The right to seek compensation is an important principle to ensure that the negotiated outcome remains balanced. It can also be a useful tool to resist requests for protection that would not be fully substantiated. However, this issue may be linked to the extent of use and duration of the applica-

26 See BRIDGeS Weekly Trade News Digest, Vol. 6, Number 22, June 12, 2002 that reports on the informal paper presented by Australia.

27 GauthiER ET AL. (2000) 
tion of an ESM. One would also have to deal with possible measurement difficulties. Other general issues that have been mentioned in this regard include the development of effective public interest tests at the national level as well as provision for short, and non-renewable sunset clauses ${ }^{28}$.

A third option could be to experiment more narrowly with safeguard-like instrument in sectors where concerns over the potentially disruptive effects of trade and investment liberalisation may be particularly strong. GATS members could subsequently decide, based on such experimentation, to extend the logic of the approach to other sectors or indeed to develop a generic instrument. The financial services industry would seem particularly well suited for such experimentation, not least because of the critical need to maintain orderly conditions of competition in the sector and promote the safety and soundness of financial systems ${ }^{29}$. It also happens to be the sector ASEAN countries, the key proponents of a GATS ESM, have consistently identified as justifying the need for emergency safeguard provisions. Negotiating efforts could thus be directed to adapting in GATS (or in countries' schedules) provisions similar to those which currently govern the progressive liberalisation of Mexico's financial markets under the NAFTA. Under the terms of the latter Agreement, Mexico was allowed to impose market share caps if the specific foreign ownership thresholds agreed to -25 and 30 percent, respectively, for banks and securities firms - are reached before 2004. Mexico may only have recourse to such market share limitations once during the 2000-04 period and may only impose them for a three-year period. Under no circumstances may such measures be maintained after $2007^{30}$. It bears noting that Mexico has not made use of such provisions even though the aggregate share of foreign participation in its financial system today is significantly higher than the thresholds described above ${ }^{31}$. Another sector where concerns over the injurious effects of post-liberalisation foreign entry arises quite frequently in developing countries concerns retail trade. Here too WTO Members could agree to experiment with sector-specific responses and derive useful policy lessons prior to agreeing on a generic instrument.

To be able to agree on an ESM by the end of the Doha negotiations, services negotiators should discuss these options and agree on a draft agreement on emergency safeguards before the Fifth WTO Ministerial taking

28 BOSWORTH (2000)

29 SAUVÉ and GILLESPIE (2000)

30 Sauvé and Gonzalez-Hermosillo (1993)

31 MATHIESON and ROLDOS (2001) 
place in Mexico in 2003. The direct link of the work done in the subsidiary bodies to the negotiations on specific commitments in Council for Trade in Services (CTS) should be sought to find a satisfactory solution to this problem. GATS negotiators will be busy studying the incoming initial requests and starting to think about potential offers to be made by the agreed March 2003 deadline. In addition, many special sessions of the Council for Trade in Services will be devoted to gauging how prepared WTO Members are to make additional commitments. The added sector-specific information arising from bilateral request-offer negotiations may very well provide the best source of information on whether and why an ESM instrument is needed and on which of the above options this instrument should best rest.

\section{Subsidies}

The question of subsidy disciplines, for which a timetable for completing negotiations was not envisaged (unlike discussions on emergency safeguards) at the time the curtain fell on the Uruguay Round, has not given rise to the same degree of debate as that on a possible ESM. For this reason, deciding on the desirability or feasibility of introducing disciplines will require a more thorough identification phase to determine the extent to which subsidies exist in services industries and the circumstances in which they may result in adverse trade or investment effects. This process has in reality only just begun among WTO Members ${ }^{32}$.

Despite the fact that via the GATS negotiation guidelines the Doha Mandate now suggests that negotiations under Art. XV shall be concluded prior to the conclusion of negotiations on specific commitments, there may well be valid reasons to temper expectations on this front. This can be witnessed by the generally disappointing experience of attempts by the OECD Industry Committee to monitor industrial subsidies, or the swiftness with which subsidy-related issues fell off the negotiating table in aborted negotiations on an OECD-anchored Multilateral Agreement on Investment.

As with safeguards, determining the feasibility of subsidy disciplines will require an analysis of the specificities of services trade. While some guidance could come from the WTO's Agreement on Subsidies and Counter-

32 See WTO document S/WPGR/W/9 (March 6, 1996), Subsidies and Trade in Services - Note by the Secretariat for initial work on this issue. 
vailing Measures (SCM), most experts agree that it is not a panacea. In particular, consideration of a countervailing mechanism would appear undesirable from both a policy and conceptual viewpoint. The questions of export subsidies, which are prevalent in large infrastructure projects, and of investment incentives, which have recently proliferated beyond the OECD area to a number of emerging economies, may however deserve further consideration, particularly in the context of discussions on how best to enhance GATS provisions relating to commercial presence and to broaden the remit of the TRIMs Agreement.

\subsection{Defining the Issue}

Art. XV of the GATS states that "subsidies may have distorting effects on trade in services". It goes on to state that "Members shall enter into negotiations with a view to developing the necessary multilateral disciplines to avoid such trade-distorting effects. The negotiations are also to address the appropriateness of countervailing procedures". Implicit in the negotiating mandate is that subsidies do in fact exist in services trade and that some, though not all, forms of subsidy practices may have trade-distorting effects. Comprehensive information is not available on the existence of subsidies in services trade. However, anecdotal evidence and a review of information contained in WTO Trade Policy Reviews suggests that sectors such as transportation, utilities, audio-visual, tourism and financial services typically benefit from some form of subsidisation in a range of countries, developed and developing ${ }^{33}$. There remains, however, limited information and analysis regarding the impact of these subsidy practices on services trade and investment.

Furthermore, beyond the challenge of better documenting the country and sectoral incidence of subsidy practices in services trade lies the equally daunting task of defining, measuring, and, if necessary, disciplining such measures under the GATS. This is an admittedly tall order given the lack of available information, the inherent difficulty in measuring trade in services and the special characteristics of services trade, notably the multiple modes of delivery such trade entails. The discussion that follows is thus largely conceptual, raising questions that may need to be considered be-

33 For first work on subsidies in the service sector by the Secretariat see WTO document S/WPGR/ W/25/Add.2 (December 12, 2000), Subsidies for Services Sectors - Information contained in WTO Trade Policy Reviews, Background Note by the Secretariat. 
fore a decision on the desirability and feasibility of new disciplines can be taken.

The GATS does not currently define the term "subsidy". For our purpose, we can borrow the GATT definition that defines a subsidy as a financial contribution by a government that confers a benefit to a recipient. Examples of trade distorting subsidies potentially include export subsidies, import displacement subsidies and production subsidies which materially impact on the price and quantity of services available for export. In addition to direct subsidies, consideration may also need to be given to situations where subsidies to goods producers may have indirect or downstream effects on services trade.

\subsection{Existing GATS Disciplines on Subsidies}

The existing GATS framework is not bereft of provisions applying to subsidies. Specifically, it is generally accepted that subsidies are considered "measures" within the meaning of the GATS and thus, the obligations of MFN and, where commitments are scheduled, national treatment are applicable ${ }^{34}$. MFN obligations are particularly relevant to the subsidy issue when there is no domestic service supplier. In such instances, MFN treatment requires that a Member is not allowed to discriminate between other Members' service suppliers.

National treatment applies to the subsidy practices of GATS signatories to the extent that the sector has been listed in a country's schedule of commitments. National treatment can exert a potentially strong discipline on the use of subsidies as it requires that governments providing subsidies to domestic services suppliers also have to make them available to foreign service providers operating in the country. However, it must be noted that the majority of GATS members have included limitations to national treatment applying to all subsidies practices. Others have done so with respect to specific modes and specific sector ${ }^{35}$. Furthermore, there is a debate as to whether the national treatment obligation extends across all modes of supply, or whether members retain the freedom to discriminate between identical services delivered via a different mode on grounds

\footnotetext{
34 The MFN clause in Art. II forbids discrimination between foreign services and service suppliers originating in different GATS Members' countries. It is a horizontal obligation, applicable to all measures affecting trade in services, in all sectors and modes of delivery.

35 Examples are found, inter alia, in the schedules of Canada, the EU, the USA, and Japan.
} 
that such suppliers are not in "like" circumstances. Also at issue are the questions of how the national treatment obligation would apply to "one off" subsidies and how the concept of "like service supplier" would be interpreted.

Further to MFN and national treatment obligations, the GATS also has articles which cover domestic regulation (Art. VI) and monopoly behaviour (Art. VIII). Services industries tend to be characterised by a higher degree of government ownership (particularly in developing countries), regulation and intervention compared to the goods producing sectors. Government regulation and monopoly concessions tend to create large, entrenched, service providers who can extend into foreign markets from a highly protected home base (through cross-subsidisation). In such instances, domestic regulatory conduct may impart a similar effect as a trade-distorting subsidy: driving prices downward in the foreign market. The GATS contains a provision on monopolies and exclusive service providers (Art. VIII) and business practices (Art. IX) that may be relevant to these circumstances.

As competition in services trade and investment intensifies, it is possible that greater pressures will develop to create a more comprehensive set of disciplines to deal with trade (and investment) distorting subsidies. The current GATS provisions (including its MFN and national treatment obligations) may not be sufficient, thereby suggesting the need to consider the development of disciplines that would be appropriate to services trade. In this regard, a useful point of departure is to look at the disciplines contained in the WTO Agreement on Subsidies and Countervailing Measures.

\subsection{Using the Agreement on Subsidies and Countervailing Measures (SCM) as a Model: Conceptual and Practical Problems}

The conclusion of the Uruguay Round achieved notable improvements in the area of subsidy disciplines. For instance, the Subsidies and Countervailing Measures (SCM) Agreement developed during the Uruguay Round provides a definition of the term subsidy, elaborates the list of prohibited practices, strengthens disciplines regarding domestic subsidies, and improves and clarifies the rules concerning the application of countervailing duties. 
The SCM Agreement defines a subsidy as "a financial contribution by a government or any public body within the territory of a Member," that confers a benefit to the recipient ${ }^{36}$. This definition includes financial contributions provided by any government body or agency, sub-federal governments, or even a private firm acting on behalf of a government. The definition also contains an exhaustive list of practices that constitute financial contributions.

In a services context, should a broader definition be adopted, which would also take into account the subsidy-like effects of regulatory interventions? Adopting an all-encompassing definition may risk developing an unwieldy instrument that could be subject to abuse. It would also certainly raise, particularly in today's more transparent negotiating environment characterised by vocal NGO advocacy, difficult issues in terms of perceived loss of regulatory sovereignty in the pursuit of legitimate public policy objectives. A broader definition of subsidy-like practices would also need to be considered in the context of today's significantly heightened culture of judicial activism in trade policy matters. It is difficult enough to determine the trade effects of a direct subsidy as it is, let alone trying to determine the financial costs and benefits bestowed from regulatory measures. Moreover, the potentially adverse or overtly protectionist effects of regulatory barriers could be dealt with more appropriately under the auspices of GATS Articles VI (domestic regulation), VII (recognition) and VIII (monopolies and exclusive service providers). As such, the current SCM definition may provide a workable basis for services trade.

Another main feature of the SCM Agreement is the "traffic light" approach to classifying subsidies. Green light subsidies are non-actionable, red light subsidies are prohibited, and amber light subsidies are actionable only if it can be proven that adverse trade effects have resulted from the government assistance. In the SCM Agreement, "green light" subsidies encompass four types of activities: generally available subsidies (i.e., subsidies not specific within the meaning of the SCM Agreement), research and pre-competitive development activities $(R \& D)$, regional development aid, and certain environmental subsidies (i.e., assistance for the adaptation of existing plants to new environmental requirement). It is interesting to note that each of these activities can constitute service sectors in their own right. If WTO members collectively deemed it appropriate in the Uruguay Round to protect such practices in the context of trade in

36 Agreement on Subsidies and Countervailing Measures, Part 1 article 1.

Reproduced with permission of the copyright owner. Further reproduction prohibited without permission. 
goods, should the same reasoning not extend to services trade and investment?

In addition to the above listed activities, it might be necessary to examine the possible ramifications for social services (education, health, and related social services). In principle, subsidies to these types of activities should not be at issue because they typically involve services rendered in the exercise of governmental authority, which are carved out under Art. $\mathrm{I}: 3$ (b) of the GATS. However, some of these sectors represent commercially tradable services, already listed in some countries' schedules. There is little doubt that this issue raises particular sensitivities in many jurisdictions that will likely require specific and careful attention in developing any acceptable subsidy disciplines. The creation of an SCM-like "green box" (or non-actionable) approach to subsidies which are granted for the pursuit of recognized social or non-economic objectives (e.g. environmental protection, provision of services in remote or disadvantaged areas) could be considered in this regard.

The SCM Agreement prohibits export subsidies and import substitution subsidies. However, before this can be transposed to services trade, it is essential to examine what it would mean in respect of each mode of supply. For mode 1, or cross-border delivery of services, the situation is roughly comparable to trade in goods, and theoretically the same prohibition could well be applicable. For mode 2, the scenario is reversed because the consumer travels to the supplier's territory to consume a service. How then might an export subsidy be applicable? A domestic producer (of a like service) would have to claim that a foreign service provider received government assistance conditional on attracting a purchaser from the domestic country to consume the service abroad. Is this realistic? For instance, would a subsidy granted by a government to a local tourism authority to build large resort hotels to attract foreign tourists constitute a prohibited subsidy? How does such a situation differ from the subsidisation of an aircraft repair facility that essentially services foreign aircraft companies?

The concept of an export subsidy also becomes quite confusing in terms of mode 3 service delivery, i.e. commercial presence. It is unlikely that a domestic government would provide a subsidy to a firm that is considering relocating or establishing a commercial presence in another jurisdiction. No export subsidy likely exists under such a scenario. On the other hand, investment incentives offered by host countries to attract invest- 
ment from abroad may clearly exert trade- and investment-distorting effects. Should the country with the most attractive package be brought before the WTO on charges of providing "unfair" subsidies? Countries often justify investment incentives as a form of economic (or regional) development assistance taken on grounds of market failure (information asymmetries, externalities) even though the trade implications of their actions can be apparent. When are investment incentives trade-distorting and when are they legitimate for public policy reasons, as recognised by GATS Art. XV? An additional challenge with regard to investment incentives concerns the possible need to address them also in the realm of goods trade - indeed ultimately in a coherent, undifferentiated manner as between goods and services trade. Doing so would go some way towards redressing the current imbalances in the TRIMs Agreement, imbalances that are arguably more prejudicial to developing country interests than to those of developed countries.

For mode 4, it is hard to think of credible examples of export subsidies affecting the temporary movement of natural persons. Is it realistic for governments to provide a subsidy for persons leaving the country? It is probably more likely that an importing country would provide a subsidy to attract skilled workers to its territory. For example, in response to widespread shortages of skilled computer engineers, a government may offer financial incentives (i.e., subsidised travel or relocation grants) for foreign skilled workers to locate within its territory. Policy makers are thus confronted with a similar situation as under mode three (commercial presence) and the phenomenon of investment or location incentives.

The above examples illustrate the potential complexity of developing disciplines on what are, at first glance, the most obvious forms of trade- or investment-distorting subsidies. The same is to be expected regarding the treatment of actionable subsidies under the SCM Agreement. The SCM Agreement does not contain an explicit definition of an "actionable" subsidy. These forms of specific subsidies are subject to remedial action if it is proven that the interests of other Members have been adversely affected. Such effects include: (1) injury to the domestic industry of an importing country, (2) nullification or impairment of GATT benefits, and (3) "serious prejudice" to the interests of another Member.

The determination of injury caused by subsidisation is an essential step in the application of countervailing duties. There would be several problems in attempting to replicate this procedure in the GATS context. To begin, 
countervailing clearly would be problematic for modes 2 through 4 because the traditional notion of imports does not readily apply. For mode 1 , there would be several implementation problems, such as problems associated with measuring and observing trade data, the conceptual difficulty of defining "like services" and "like domestic services providers", and practical enforcement difficulties, not least of which involves electronic delivery. These problems, which parallel those described earlier in an emergency safeguard context, would also be compounded by the difficulty of measuring the degree of subsidisation to be countervailed. Given the intangible nature of many types of services transactions, calculating "per unit" subsidisation rates would also pose formidable challenges ${ }^{37}$.

Many of the same difficulties would probably be present in attempting to apply a serious prejudice test to services trade. However, the serious prejudice provision in the SCM Agreement does contain specific tests of total ad valorem subsidisation that might be relevant in a service context. In particular, it is worth noting that the SCM Agreement states that serious prejudice is deemed to exist when the overall rate of subsidisation exceeds $15 \%$ of the total funds invested in a new start-up operation. In a sense, this resembles closely a plausible scenario under mode 3 , whereby the subsidisation is given to entice the establishment of a commercial presence by a service provider.

In short, some elements of the SCM Agreement would appear relevant to a consideration of subsidy disciplines in services trade. The definition of subsidies would offer a starting point and the traffic light approach would offer a possible structure to work from, although adjustments would be needed to reflect the particular nature of services trade (in particular the multiplicity of modes of supply). However, it would appear that developing a countervailing duty mechanism would pose serious practical difficulties.

\subsection{Options for Moving Forward}

Before embarking on the creation of disciplines, it is essential to reflect further on the basic question of whether trade distorting subsidies are

37 It is also debatable whether it would be advisable to even contemplate a countervailing duty mechanism for services trade. Countervailing implies the use of an unilateral remedy to try to resolve what is inherently a bilateral or multilateral issue - at least two governments are involved, the one providing the subsidy and the complaining party. 
sufficiently pervasive in services trade to warrant rule-making. It remains to be seen whether additional national treatment commitments throughout all modes and the elimination of most MFN exemptions cannot help to greatly reduce the trade-distortive effects of subsidies. There is, additionally, the question of political will (in both developed and developing countries, and most acutely in countries characterised by federal political systems) to curtail regulatory sovereignty in this area. The lessons one may draw from recent negotiations in the subsidies area - including the lack of progress in a GATS setting - reveals a decidedly limited political appetite for forward movement ${ }^{38}$. Moreover, the sector-specific implications of such an agreement have yet to be discussed. One can be sure, for instance, that WTO Members will not be eager to put into question their subsidy schemes in politically sensitive areas (e.g. audiovisual services, health). But the lack of pressure necessary for the creation of such an agreement seems to be a general phenomena. Apart from a few trade economists that worry from time to time about the potentially trade- and investment-distorting effects of subsidies, not even the service industry has lobbied much for the adoption of such disciplines.

The lack of progress may here again be due to the fact that until now this topic was dealt with by a subsidiary working party (WPGR) concerned primarily by the issue of emergency safeguards. Moreover, as noted earlier, it is questionable whether the way the subsidiary bodies of the Council for Trade in Services will work outside the context of a wider round of negotiations, which constitute the most promising way of making progress on issues that are both politically sensitive and technically complex. As with emergency safeguards, it could be that the integration of this topic into the Doha Round - and its ensuing greater visibility - may provide more room for progress on this question. Also, it should be noted that as a result of the Doha mandate, the issue now has an implicit deadline attached to $\mathrm{it}^{39}$. Nevertheless, there is still a long way to go.

Confirmation of subsidy practices is essential in order to gain a better understanding of their potential impacts on trade in services. A general notification and transparency provision along the lines of that contained in Art. XXV of the SCM Agreement might represent a useful starting point. In addition, it bears noting that the SCM Agreement already provides scope for remedial action against unfair subsidisation of services embo-

39 Prior to the conclusion of negotiations on specific commitments. 
died in goods. It may thus be that some of the potential concerns with trade distorting subsidisation in services identified from a conceptual standpoint are already taken care of by existing rules on goods trade ${ }^{40}$.

From a fundamental standpoint, two issues may warrant further attention: (1) a prohibition on export subsidies, and (2) the issue of investment incentives in the context of establishment of a commercial presence. Export subsidies are intrinsically antithetical to fair trade. For reasons mentioned above, their curtailment might only be workable for cross-border trade (i.e. mode 1), which once again raises the question of whether it could create distortions between modes of supply, in particular the possibility of circumventing the disciplines by delivering the service via a different mode.

As for the question of investment incentives, the relationship with existing GATS obligations pertaining to commercial presence on the one hand and the serious prejudice provision on the other hand, suggest that not only could it be addressed incrementally, but that new multilateral rules in this area could represent a useful complement to existing disciplines. The domestic sensitivities that both of these questions give rise to, and the tepid political support for moving forward in these areas, cannot however be easily dismissed.

There remains, finally, the challenge of addressing the development dimension of any future subsidies regime for services, recognising the role that subsidy measures may play in building-up service sector capabilities in developing countries and possibly allowing for greater doses of flexibility (or making certain types of support measures non-actionable depending on countries' level of development). The latter issue which has received scant attention to date in discussions among WTO Members, would almost certainly assume greater importance should negotiations enter a more operational phase.

\footnotetext{
40 An example of the latter can be found in the Illustrative List of prohibited export subsidies annexed to the SCM Agreement, which makes reference to transport and freight charges, as well as to the provision by governments of services more generally.
} 


\section{Government Procurement ${ }^{41}$}

\subsection{Services procurement: economic and empirical consideration}

Services are often the largest category of purchases by governments - increasingly so in countries which have been pursuing outsourcing and contracting strategies ${ }^{42}$. An increasing number of governments have been pursuing far-reaching efforts to enhance the efficiency of public services by directly subjecting production units to competitive market forces ${ }^{43}$. Examples include privatization of state-owned enterprises; encouraging entry into sectors traditionally reserved for public entities (e.g., utilities) and contracting out activities to the private sector. The efficiency gains associated with such policies can be significant ${ }^{44}$.

At present, comparable and disaggregated data on procurement of services are not available on a cross-country basis. In particular, data on expenditures by sub-central government entities are not comprehensive. How much of what is procured could be subject to international competition is also largely unknown, as it depends on a variety of factors, including the type of services, the thresholds applying to competitive bidding, and the policy stance that is taken towards buying from non-nationals, favouring specific groups in society (e.g., small enterprises, minority-owned businesses), etc. Little is known also regarding the policy stance taken towards procurement of services. Many countries maintain procurement regimes affording various price and non-price preferences to national suppliers. However, in most cases there is no data on the extent to which such provisions are truly binding, for instance with regard to local affiliates of foreign firms. Often, the latter firms will be treated as "domestic", so that the effect of discrimination may be minimal as long as establishment (or foreign direct investment) is the preferred mode of supply. However, some governments may differentiate between locally established firms on nationality of ownership grounds.

Developing country markets for services procurement are generally smaller than those of high income countries, not only in absolute size, but also

\footnotetext{
41 The analysis that follows draws largely on the perceptive insights developed in recent work by SIMON EVENETT and BERNARd HoEKMAN at the World Bank (see EvenetT and HoEKMAN 2000).

42 HOEKMAN and MAVROIDIS (1997)

43 Low, MatToO and Subramanian (1997)

44 DOMBERGER, HALL and Li (1995) survey the empirical literature on the price and quality effects of competitive tendering and conclude that: (i) savings on the order of 20 percent are common; and (ii) that these savings do not come at the expense of quality.
} 
relative to purchases of goods. The thresholds that are embodied in the GPA would likely be more binding for developing countries (though few of them are actually GPA signatories) as the average size of contracts can be expected to be smaller than in higher income countries. What is more, most developing economy settings possess fewer national suppliers than do industrialised nations. This lessens the actual scope for discriminating in favour of domestic industries ${ }^{45}$. It also bears recalling that many expenditures by developing country governments are financed through official development assistance funds, both bilateral and multilateral. As official bilateral development aid is usually tied to procurement from the donor country; recipient countries cannot subject purchases using such finance to international competition ${ }^{46}$.

The economic effects of procurement discrimination will depend prominently on whether the products that are purchased are tradables or not. In the case of services procurement, many products will typically not be tradable. When trade is not feasible, a government's FDI policy stance becomes a key determinant of the effect of its discriminatory procurement policies. Indeed, problems of asymmetric information and monitoring costs often imply that governments will prefer to source from local firms, increasing the incentives for foreign firms to contest procurement markets through FDI. The intangible nature of many services implies that asymmetries of information are likely to influence the nature of contracting - increasing the likelihood of de facto discrimination as purchasers often use the implicit promise of a long term relationship to induce suppliers to deliver high quality services in a timely fashion. From a WTO perspective, two important issues flow from the following considerations: first, whether there are barriers to entry for prospective service suppliers through commercial presence, and second, how entities decide who qualifies as a "local" bidder (via rules of origin in procurement agreements). An important determinant of the effect of a government's procurement

45 For example, in the $1980 \mathrm{~s}$, investments in the power sector accounted for one quarter of total public investment in developing countries. In most cases the associated capital equipment could not be procured domestically even if governments pursued discriminatory purchasing policies (EvENETT and HOEKMAN 2000).

46 Work by Bernard Hoekman at the World Bank has drawn attention to the importance of aid flows as a share of government expenditure. Aid finances a significant share of total purchases of goods and services by developing countries' governments. The ratio of multilateral flows to expenditure is about 18 percent for low income countries, while total aid (including bilateral aid) is equivalent to 35 percent of total expenditures on goods and services. For lower middle income nations, total aid accounts for 16 percent of expenditures, for upper middle income economies the figure drops to 6 percent. This suggests that for poor countries in particular, much procurement cannot be subjected to preferential policies, even if governments would prefer to do so. This significantly reduces the potential benefits for foreign suppliers interested in selling services in these markets (HOEKMAN 1998). 
practices will also derive from the host government's competition policy, the ambit and enforcement of which can determine whether the presence of a small number of suppliers is the result of artificial barriers to entry.

\subsection{Policy and negotiating implications}

The absence of general rules on public purchasing practices is an obvious shortcoming of the WTO. A question confronting policymakers is whether this is in fact an important problem, and if so, what to do about it. On the multilateral front, the WTO Members have now taken an important new step that is included in the Doha Mandate ${ }^{47}$. They have decided to undertake negotiations for a multilateral agreement on transparency in government procurement after the Fifth Session of the Ministerial Conference. These negotiations shall build on the progress made in the Working Group on Transparency in Government Procurement and shall take into account the participants' development priorities. Most importantly, WTO Members have decided to concentrate on transparency issues rather than restricting the scope of countries to give preference to domestic suppliers.

Considering the above development, the question arises of whether existing stand-alone disciplines should be incorporated into the General Agreement on Trade in Services (GATS), or whether this more general approach covering both goods and services is preferable. Also, one must ask the question whether the exclusive focus on transparency in the multilateral agreement and the postponement of negotiations' beginning until the end of 2003 are acceptable in the GATS context. Stated differently, can a robust case be made for embedding disciplines on government procurement in the GATS which may go further than the issue of transparency? Much as the question seems disingenuous in the light of the GATS negotiating mandate to do precisely that, some of the above considerations begin to explain the scepticism that a number of experts have voiced regarding the desirability of such disciplines ${ }^{48}$. There are, indeed, strong grounds to believe that the domestic and foreign welfare effects of discriminatory procurement regimes may well be negligible and of a transient nature to the extent that domestic markets remain contestable.

47 WTO document WT/MIN/(01)/DEC/W/1 (November 14, 2001), Ministerial Declaration of the Ministerial Conference (Fourth Session), page 5, para. 26.

48 See EvenetT and Hoekman $(1999,2000)$ and Bosworth $(2000)$. 
An important characteristic of procurement markets being the fact that many procured services may not be viably supplied on a cross-border basis, commercial presence typically represents the preferred route in light of the natural advantages that flow from local establishment. It is for this reason that a host country's foreign investment regime assumes crucial importance in maximizing the economic efficiency and domestic welfare gains from an open procurement regime.

Clear and practical policy implications flow from the above analysis. Since the economic damage inflicted by discriminatory procurement policies depends on the contestability of markets, the optimal policy response should be to encourage open and competitive markets, promote investment regime liberalisation and vigorously enforce competition policy. Such a policy trinity course is one that many - though not all - countries can pursue on a unilateral basis ${ }^{49}$. Priority attention should thus be given in domestic policy to the removal of barriers to entry and presence in markets. In negotiating terms, WTO members might be well advised to deploy greater efforts in enhancing market access and national treatment commitments under the GATS, particularly as regards mode 3 (commercial presence), than in developing GATS-specific disciplines on government procurement. They may also usefully think of the best ways of addressing investment-related matters more broadly in the WTO or, more narrowly, enhancing the "investment friendliness" of the GATS ${ }^{50}$.

Although trade and investment liberalisation and an active competition policy may ultimately obviate the need for multilateral procurement disciplines applicable to both goods and services, it is important to pay attention to the need to promote transparency in procurement as a means of reducing the scope for corruption and rent-seeking. This is in fact the approach that is currently being pursued by WTO members, suggesting once again that separate disciplines on government procurement of services in the GATS may well be of limited value and indeed perhaps unnecessary.

\section{Concluding Remarks}

It is generally believed that the art of creating trade policy strikes a balance between what "policy makers practice and what economists preach"

49 At year-end 2000, only 87 of the WTO's 140 member governments possessed a competition regime.

50 See SAUVÉ and WILKIE (2000). 
(THARAKAN 1995). This is certainly true when considering the appropriateness of an ESM and subsidy disciplines in services trade. Several elements must be carefully considered in this regard, spanning issues of economic rationale and conceptual underpinnings, commercial interests, practicability, enforceability and certainly negotiability.

The question of an emergency safeguard measure in services trade has been on the agenda for several years now. The debate has evolved but still appears somewhat elusive, as is reflected in the decision by GATS members to extend for a fourth time, to March 15, 2004 (the deadline for completing negotiations on an ESM). A stocktaking exercise will take place during the Fifth Ministerial Meeting. The very desirability of an ESM remains an open question for many of the WTO's most influential Members. The test of "unforeseen circumstances" which is instrumental to the consideration of an ESM remains fragile, simply because it is difficult to understand how it can be made operational via objective tests. Even if the desirability is accepted, one must consider the feasibility where it is apparent that there are several hurdles to overcome, for instance: the modes of delivery, particularly commercial presence, the impact of technology, the general paucity of statistical information required for credible injury determinations, let alone the economics and the diversity of trade interests. The paper has reviewed, without advocating any particular course of action, the various options confronting the negotiating community. Such proposals range from a full-blown, GATT-like, instrument to a more cautious approach of experimentation in the financial services sector with a view to subsequent generalisation. The paper cautions however that the clear political expectation on the part of many developing countries that concrete disciplines must arise from the current discussions suggests that it is likely that the GATS will feature some form of ESM in future, although its ultimate substantive provisions and operational modalities remain to be determined.

The question of subsidy disciplines has not to the same degree given rise to debate and consideration as that of safeguards. The paper suggests that the desirability of disciplines in this area will require a more thorough identification phase to determine the extent to which subsidies exist in services industries and result in adverse trade or investment effects. As is the case for safeguards, the feasibility of subsidy disciplines will need to factor in the specificities of services trade and investment. While some guidance could come from the SCM Agreement, it is not a panacea. In particular, consideration of a countervailing mechanism would appear un- 
desirable, from both a policy and conceptual standpoint. The question of export subsidies, and investment incentives, particularly in relation to the existing GATS obligations on commercial presence, might however deserve further consideration.

Procurement regimes for services, even if explicitly discriminating against foreign suppliers, are unlikely to have major repercussions on domestic or foreign welfare so long as markets are contestable. The priority issue from a developing country perspective may therefore lie more in removing barriers to access (i.e. trade) and presence (investment) in goods and services markets and enforcing domestic competition laws than in developing a GATS-anchored set of procurement disciplines. Even in the narrower confines of services trade, greatly expanding the market access and national treatment commitments under the GATS may largely obviate the need for a multilateral rule-making response. Moreover, market access is a precondition for foreign firms to contest procurement markets. If they are not permitted to access the market - which in a procurement context practice typically means establishing a commercial presence procurement regimes and possible multilateral disciplines may well be of little consequence.

This is not to say that there is no value in agreeing on any multilateral disciplines on procurement. There are significant potential gains from disciplines which ensure that procurement mechanisms become more transparent, thereby reducing the scope for corruption and rent-seeking. Even if procurement discrimination may have little impact on the efficiency of resource allocation in the long run, corruption and rent-seeking which aim to influence the allocation of procurement contracts are costly and inimical to the process of sustainable development.

Any procurement disciplines that relate to process and transparency should be horizontal or across-the-board, as there is no compelling reason to treat procurement of services differently from procurement of goods ${ }^{51}$. This latter consideration yet suggests another argument to resist efforts at pigeon-holing procurement disciplines under the GATS (all the more so as the GPA already covers services transactions, albeit on a plurilateral basis). Stronger returns on scarce negotiating efforts are likely to arise from ongoing attempts to agree on rules with regard to transparency in public purchasing.

51 See Hoekman and Mavroidis (1997a). 


\section{References}

BAldwin, Robert E. (1992): Assessing the Fair Trade and Safeguards Laws in Terms of Modern Trade and Political Economy Analysis; in: The World Economy, Vol. 15, No. 2, (March)

Bosworth, Malcolm (2000): "Comment"; in: Sauvé, Pierre and Robert M. STERn (eds.): GATS 2000, New Directions in Services Trade Liberalisation, Washington, D.C.: Brookings Institution Press, pp. 211-17

Domberger, Simon, Christine Hall and Eric Ah Lik Lee (1995): The Determinants of Price and Quality in Competitively Tendered Contracts; in: Economic Journal (105), pp. 1454-70

EvenetT, Simon J. and Bernard M. Hoekman (1999): Government Procurement: How Does Discrimination Matter?; World Bank, mimeo EvenetT, Simon J. and Bernard M. HoEkman (2000): Government Procurement of Services and Multilateral Disciplines; in: SAUVÉ, Pierre and Robert M. Stern (eds.): GATS 2000, New Directions in Services Trade Liberalisation, Washington, D.C.: Brookings Institution Press, pp. 143-64

Gauthier, Gilles ET AL. (2000): Déjà Vu or New Beginning for Safeguards and Subsidies Rules in Services Trade?; in: SAUVÉ, PIERRE and Robert M. STERn (eds.): GATS 2000, New Directions in Services Trade Liberalisation, Washington, D.C.: Brookings Institution Press, pp. 16583

HOEKMAN, BERnARD M. (1998): Using International Institutions to Improve Public Procurement; in: World Bank Research Observer (13), pp. 249-69

Hoekman, Bernard M. and Petros C. Mavroidis (eds.) (1997): Law and Policy in Public Purchasing: The WTO Agreement on Government Procurement; Ann Arbor: University of Michigan Press

Hoekman, Bernard M. and Petros C. Mavroidis (1997a): Multilateralizing the Agreement on Government Procurement; in: HoEKMAN, Bernard M. and Petros C. Mavroidis (eds.) (1997): Law and Policy in Public Purchasing: The WTO Agreement on Government Procurement; Ann Arbor: University of Michigan Press, pp. 289-312

INSIDE US TRADE (2000): ASEAN Unveils Services-Specific Safeguard Paper; Major Players Cool; in: Inside US Trade (31 March)

Low, Patrick, A. Mattoo and A. Subramanian (1997): Government Procurement in Services; in: Hoekman, Bernard M. and Petros C. Mavroidis (eds.): Law and Policy in Public Purchasing: The WTO 
Agreement on Government Procurement; Ann Arbor: University of Michigan Press, pp. 225-42

Mathieson, Donald J. and Jorge Roldos (2001): The Role of Foreign Banks in Emerging Markets; Paper prepared for "Open Doors: Foreign Participation in Financial Systems in developing Countries", The World Bank, International Monetary Fund and Brookings Institution $3^{\text {rd }}$ Annual Financial Markets and Development Conference, New York City, (19-21 April)

Messerlin, Patrick (1997): The Emergency Safeguard Measures in GATS; mimeo, Note prepared for a seminar hosted by the Permanent Mission of Thailand to the WTO, Geneva, (September)

OECD (2002): GATS: The Case for Open Services Markets; Paris: Organisation for Economic Co-operation and Development

Sauvé, Pierre and Brenda Gonzalez-Hermosillo (1993): Implications of the NAFTA for Canadian Financial Institutions; in: C.D. Howe Commentary, No. 44, Toronto: C.D. Howe Institute, (April)

Sauvé, Pierre and Christopher Wilkie (2000): Investment Liberalisation in GATS; in: SAUVÉ, Pierre and Robert M. STERn (eds.): GATS 2000, New Directions in Services Trade Liberalisation; Washington, D.C.: Brookings Institution Press, pp. 331-63

Sauvé, Pierre and James Gillespie (2000): Financial Services and the GATS 2000 Round; in: Litan, Robert E. and Anthony SANTOMERo (eds.): Brookings-Wharton Papers on Financial Services 2000; Washington, D.C.: Brookings Institution Press, pp. 423-52

Tharakan, P.K.M. (1995): The Political Economy of Contingent Protection; in: The Economic Journal, Vol. 105, No. 433

WTO (2001): GATS - Fact and Fiction; Geneva: WTO

Reproduced with permission of the copyright owner. Further reproduction prohibited without permission. 
Reproduced with permission of the copyright owner. Further reproduction prohibited without permission. 